\title{
Dynamics of Japanese and Chinese Security Policies in East Asia and Implications for Regional Stability
}

\author{
Elena Atanassova-Cornelis \\ Catholic University of Leuven \\ Carmen Amado Mendes \\ University of Coimbra
}

This article examines the dynamics of Japanese and Chinese post-Cold War security policies in East Asia and assesses the implications for regional stability. To this end, the discussion explores elements in both countries' security policy behavior, and SinoJapanese relations that have a stabilizing and/or destabilizing impact on the region. The article argues that, on the whole, Japanese and Chinese security policies have contributed to more stability than instability. Although the security dilemma between Japan (and the United States) and China may have become more pronounced, the balance of power currently maintained may be assessed in positive terms for the region. In addition, SinoJapanese competition for influence has led to strengthening East Asian institution building and thereby fostered stability. While there is ground for cautious optimism regarding the future of Sino-Japanese cooperation, mutual strategic distrust between Tokyo and Beijing will underpin the security dilemma and their competitive policies in the region.

Key words: China, East Asia, Japan, security

\section{Introduction}

$\Gamma$ he contemporary geopolitical and strategic landscape in East Asia ${ }^{1}$ is shaped 1 by a power shift, unseen in the region's modern history: the simultaneous rise of Japan and China. Although Japan in the post-Cold War period has continued to pursue a foreign policy approach largely based on economic and nonmilitary instruments of power, it has sought a more "normal" role in East Asian, as well as global, security affairs. ${ }^{2}$ Faced with a new military threat from the Democratic People's Republic of Korea (DPRK or North Korea) and uncertainties about the implications of China's rise in the long term, Tokyo is seen to have attached greater importance to strengthening Japan's defense posture and security alliance with Washington. Having seen nearly 30 consecutive years of 
spectacular economic growth, China, for its part, has been consolidating its status as a major regional power by modernizing its armed forces, asserting its territorial claims in East Asia, and enhancing its diplomatic and economic role in the region. While promoting a defensive image, Beijing has increasingly sought to undermine U.S. primacy in East Asia, which it considers as a threat to its national security interests as well as reduce Japan's regional influence. As Japan and China each have responded to the new post-Cold War strategic environment in East Asia by redefining their respective security priorities, mutual suspicion of the other's strategic intentions has increased, while rivalry between Tokyo and Beijing for regional leadership has become more accentuated. In turn, this has made the question of East Asian stability more relevant than ever.

It is in the context of the above discussion that this article examines the dynamics of Japanese and Chinese security policies in the region. In particular, the article explores elements in both countries' security policy behavior and Sino-Japanese interactions that could have a stabilizing and/or destabilizing impact on East Asia. In this way, it seeks to assess the implications for regional security of Japan's and China's adjustment to the post-Cold War strategic environment.

The article starts by outlining the post-Cold War external and domestic context of security policy in both countries. The discussion then examines the ways Japan and China have tackled what each side sees as their respective security concerns-for Japan, this has been North Korea and increasingly China, while for China, this concerns the United States and its alliance with Japan. The analysis underscores the "action-reaction" dynamics between Tokyo and Washington, and Beijing, by alluding to the emerged security dilemma in East Asia, and by exploring the recent trend toward military buildup and potential arms race in the region. The article then goes on to examine the way Tokyo and Beijing have each promoted regional institution building and thereby contributed to a strengthening of multilateralism in East Asia. It is argued that whereas in Northeast Asia recent developments suggest willingness on the part of both Japan and China to use various fora to jointly address issues of common concern and arguably alleviate the security dilemma, in the wider Asia-Pacific region and here especially in Southeast Asia, Japan and China are increasingly seen as pursuing regional initiatives and using soft power ${ }^{3}$ in order to compete for influence. The article concludes by making several observations with regard to the implications of Japanese and Chinese security policy behavior for stability in East Asia.

\section{The External and Domestic Context of Japanese and Chinese Security Policies}

The structural change in the international system brought about by the end of the Cold War dramatically altered the strategic perceptions of both Japan and China. For Japan, North Korea has emerged as its immediate security threat due to Tokyo's concerns about the DPRK's nonconventional military capabilities, notably Pyongyang's nuclear program and missiles capable of targeting Japan's major cities. Japan has felt intimidated by North Korea's belligerent behavior since the 1994 nuclear crisis, and its concerns have arguably intensified in the wake of the DPRK's 2006 and 2009 missile launches and nuclear tests. ${ }^{4}$ Indeed, 
the worries are now that Pyongyang has possibly made progress in developing smaller nuclear warheads, which could be mounted on ballistic missiles and hence targeted at Japan. The perceived North Korean security threat is additionally complicated by several cases of Japanese citizens being kidnapped by North Korean agents along Japan's coastal areas in the 1970s and 1980s. Finally, the repeated incursions of North Korean spy ships into Japanese territorial waters-the most dramatic incident being in 2001 when the Japanese Coast Guard was forced to chase and sink one such vessel-have further contributed to a significant shift in Japan's perception of the DPRK.

While North Korea's nuclear and missile programs have become an immediate catalyst for Tokyo's redefiniton of its security policy, the rise of China has presented Japan with additional challenges in the long term. These include concerns about the modernization of China's nuclear and missile potential and Beijing's strategic intentions in the region. Tokyo is especially worried about the expansion of China's naval and air military capabilities, as it would allow Beijing to project its power into the East and South China Seas, where Japan's sea lanes of communication (SLOC) stretch. Indeed, for a resource-poor Japan, a resource-hungry China is a strong competitor over energy supply sources. An example of a mounting Sino-Japanese rivalry for energy resources is the ongoing territorial dispute between Japan and China about the Senkaku/Diaoyu Islands in the East China Sea, as it is believed that the waters around the islands contain large oil and gas reserves. ${ }^{6}$

As in the case of Japan, the end of the Cold War led to a profound change in Chinese strategic perceptions. For Beijing, the main question has become how to deal with U.S. preponderance in East Asia and, by extension, with Japan as America's main regional ally. The People's Republic of China's (PRC's) external security concerns have been driven by internal motivations. Indeed, it has been the priority for the Chinese Communist Party's (CCP's) leadership to preserve the legitimacy of its regime and ensure domestic political stability by means of sustained economic growth (Saunders, 2008). Additionally, the perception that China has a legitimate right to retribution for past "humiliation," notably regarding Japan, and the goal of "regaining" lost territories, including Taiwan and the disputed islands in the East China Sea (Terrill, 2005), have influenced Beijing's foreign policy behavior. The overall result has been the PRC's increased involvement in East Asian affairs with a view to promoting a regional environment conducive to the realization of Beijing's objectives, securing access to energy resources, and, last but not least, expanding China's regional influence.

Beijing's priorities in East Asia arguably involve achieving a dominant position vis-à-vis Japan and, perhaps more importantly, reducing America's influence in the region, especially in Southeast Asia-what has been called the "Chinese Monroe Doctrine" (Kurlantzick, 2006; Terrill, 2005). Chinese concerns about a perceived U.S. hegemonic role in East Asia have been aggravated by Tokyo's willingness in the post-Cold War era to strengthen its defense posture and reinforce the alliance with Washington, thereby assuming a larger regional and global security role. This security activism of Japan, mostly accentuated during the term of former Prime Minister Koizumi Junichiro (2001-2006) and referred to as Japan's "normalization," was viewed by Beijing as being channeled through 
a strengthened U.S.-Japan alliance and encouraged by the George W. Bush administration $(\mathrm{Wu}, 2005)$. It is in this context that the PRC came to perceive Japan as a major tool in America's strategy aimed at balancing Chinese power and maintaining U.S. regional security dominance (Wu, 2005). In turn, this served to exacerbate Sino-Japanese mutual strategic mistrust, which, as will be discussed below, was fueled by the changing domestic context of security policy in both countries.

In Japan, there has been a rightward shift in its domestic politics, which has been translated into Tokyo's increased willingness to strengthen Japan's security posture and balance (jointly with the United States) the rising power of China. The 1990s saw the end of the one-party governance of the conservative Liberal Democratic Party (LDP) ${ }^{7}$ and the demise of the parliamentary Left. As a strong supporter of the U.S.-Japan alliance since the postwar period, the LDP's traditional emphasis in foreign policy was put on the development of Japanese economic power, alignment with the United States, and pursuit of minimal military rearmament-a strategy known as the "Yoshida Doctrine." With the rise to power of more nationalistic and conservative LDP politicians-the most notable examples being former prime ministers Koizumi, Abe Shinzo (2006-2007), and Aso Taro (2008-2009) - Japan was seen to attach greater significance to the strengthening of its defense posture and to the deepening of its security ties with the United States. In turn, the marginalization of the socialists (a strong advocate of Japan's strict adherence to Article 9 of the postwar Constitution of 1947) meant that a major constraining force on the LDP's security ambitions was removed. ${ }^{8}$ Article 9 increasingly came to be seen by a number of conservative LDP politicians, notably Koizumi and Abe, as a major barrier to a larger, or "normal," security role for Japan. Although the majority of the Japanese oppose Article 9 revision, the people have gradually come to accept a strengthened military posture of the Self-Defense Forces (SDF) in matters of national defense. ${ }^{9}$ Indeed, this is due to the changed threat perceptions, especially the Japanese public's increased concern about North Korea and China. The Koizumi factor should not be underestimated either, as his extraordinary public popularity arguably enabled him to stimulate enhanced nationalism and boost the "China threat" view within the Japanese society.

A contributing factor to this conservative shift is the perceived economic decline of Japan, especially considered against China's spectacular economic growth. Indeed, Tokyo's postwar foreign policy strategy emphasized a comprehensive approach to security ${ }^{10}$ and was largely based on the country's "everexpanding economic muscle" (Pempel, 2007, p. 111). However, Japan's stagnant economy in the 1990s and the contrasting growth of its neighbor have stimulated greater willingness on the part of its political elites to pursue a more assertive (albeit U.S.-centered) security policy, as well as strengthen Japan's diplomatic profile in East Asia.

In China, a major feature of the domestic context of its foreign policy has been the rise of nationalism. Chinese nationalism has a strong anti-Japanese component and has been used by the CCP leaders primarily to ensure the legitimacy of their regime and internal political stability. The rise of nationalism may be attributed to both historical factors-China's search for pride and international recognition given its past "humiliation" by the West and, more 
dramatically, Japan - and ideological changes - progressive evolution in the PRC from communism to nationalism in an era when communism has lost much of its appeal after the dissolution of the Soviet Union.

As mentioned earlier, domestic stability has been seen by the PRC's political elites as being directly linked to the successful achievement of the country's primary goal of sustained economic growth. The realization that the "China threat" perception in East Asia may jeopardize that goal, and hence result in containment by the United States as well as other Asian countries, has led Beijing to adopt reassuring policies toward China's neighbors, including by means of promoting its image as a benign rising power and improving bilateral ties (Foot, 2006). Such an approach however, has not been successful with regard to the PRC's relations with Tokyo, largely due to the domestic sensitivity of the issue of Japan's historical legacy in China.

Indeed, bilateral disputes over the interpretation of history during the Koizumi premiership, especially due to his yearly visits to the Yasukuni Shrine, were at the bottom of the unprecedented deterioration in Sino-Japanese relations throughout his term in office. Given that there are 14 Class A war criminals enshrined in Yasukuni in addition to 2.5 million Japanese soldiers, Beijing regarded Koizumi's pilgrimages as an attempt by Japan to legitimize its past aggression and refused to hold summit meetings with Tokyo. The heightened anti-Japanese public sentiment in China was mirrored by increased negative perceptions of the PRC among the Japanese people. Beijing's rising military power and especially the perceived lack of transparency with regard to its national defense policy, as well as (what has been seen as) its assertiveness in acquiring energy resources in the disputed waters in the East China Sea, have arguably contributed to apprehensions in Japan of China's future potential dominance in East Asia. Although Koizumi's successors have abstained from visiting the shrine, and Japan's diplomatic ties with the PRC have improved since 2006, mutual distrust has continued to define Sino-Japanese relations. Indeed, despite the increased economic interdependence since the 1990s and a number of common interests in East Asia, Japan and China have viewed one another as strategic rivals rather than partners. As will be illustrated below, the dynamics of their security policies in the region have reflected these negative mutual perceptions.

\section{Japanese and Chinese Security Policies in East Asia: Security Dilemmas and an Arms Race}

Mutual suspicion between Japan and China and diverging threat perceptions have contributed to a more pronounced trend for security dilemmas and have increased the potential for an arms race in East Asia.

In the case of Japan, its primary focus has been on dealing with the North Korean military threat and balancing Beijing's rising power by relying on the United States. Tokyo has responded to China's rise with a major adjustment in its strategy, namely from one based primarily on accommodating the PRC to one combining economic engagement with balancing (Mochizuki, 2007). The balancing aspect has been largely represented by strengthening Japan's alliance with the United States (external balancing) together with its own military capabilities (internal balancing). 
China, for its part, has pursued what has been seen as a defensive approach (Terrill, 2005) driven by domestic considerations, namely the central goal of economic development. At the same time, this approach is reflecting Beijing's search for increased regional (and global) presence in order to facilitate the achievement of its internal policy objectives. While China has sought to accommodate U.S. hegemony, it has also, with focus on the PRC's interests, hedged against a possible negative impact of America's dominance, especially in East Asia (Foot, 2006). This hedging is to be seen in Beijing's more active regional diplomacy (to be discussed later in this article) and, equally important, China's focus on strengthening its military capabilities in order to address its core national security interest (i.e., the Taiwan issue). In this context, developments in the U.S.-Japan alliance and Japanese security policy since the 1990s have been viewed by the PRC as a potential threat to the status quo across the Strait.

\section{Security Dilemmas: The U.S.-Japan Alliance and China}

It may be argued that North Korea's missile and nuclear ambitions have been at the bottom of a major change in the security dynamics between the U.S.-Japan alliance and China. The U.S.-Japanese response to the nuclear threat posed by the North has created a security dilemma between Tokyo and Washington, and Beijing by having an impact on the Taiwan issue.

For Japan, the DPRK's missile and nuclear programs have been seen as "a direct threat to peace and stability in the East Asian region, including Japan" (Ministry of Foreign Affairs, Japan, 2004, p. 7) and "a destabilizing factor not only for the Asia-Pacific region but also for the entire international community" (Ministry of Defense, Japan, 2008, p. 33). Tokyo's sharpened political rhetoric toward the North was underscored by describing the 2006 missile launches as "a matter of grave concern, including from the viewpoint of the security of Japan, and the peace and stability of the international community" (Ministry of Foreign Affairs, Japan, 2007, pp. 3-4). From a Japanese perspective, therefore, the strengthening of its alliance with America since the 1990s has been seen as a necessary means to safeguard its national security interests.

In the wake of the first North Korean nuclear crisis, in 1997 the United States and Japan revised the bilateral defense guidelines. As the guidelines committed the SDF to extend noncombat rear-area support to the U.S. military during regional contingencies, in essence, they broadened the alliance's scope from a narrow focus on the defense of Japan (which was the case during the Cold War) to include regional security crises. The adoption of the guidelines, however, increased the significance of the Taiwan issue in the relations between China, and Japan and the United States, and arguably the potential for regional instability. Some Chinese officials expressed concern that while Tokyo and Washington saw the guidelines as "safeguarding regional security," the new agreement would in fact "threaten the peace and stability of the region" ("China Slams," 1999). In particular, the ambiguous concept "situations in areas surrounding Japan" mentioned in the guidelines created apprehension in Beijing that a Taiwan conflict would fall within the remit of U.S.-Japan security cooperation. Although both U.S. and Japanese officials argued that the phrase had a "situational" and not a "geographical" interpretation, the refusal by Tokyo and Washington to explicitly rule Taiwan in or out was essentially perceived by Beijing as an interference in 
cross-Strait relations (Green, 2003). To be sure, the revision of the guidelines took place after the 1995 Chinese nuclear tests and the 1996 Taiwan Strait crisis. Accordingly, while China used the 1996 missile tests to maintain what it regarded as the status quo, by seeking to prevent Taiwanese independence, Japan and the United States reinforced their stance on the status quo by strengthening the alliance in the face of the looming North Korean threat (Green, 2003), but arguably also in response to Beijing's more assertive behavior. As far as Sino-Japanese relations are concerned, it is since the mid-1990s that mutual strategic mistrust has become a major driving force of their interactions, underscoring the presence of a security dilemma and hence having a potentially negative impact on stability in East Asia.

Following the September 11, 2001 terrorist attacks on the United States, the unprecedented strengthening of the U.S.-Japan alliance under the Bush-Koizumi partnership highlighted the strategic convergence of the two allies on traditional security issues. However, this had an adverse effect on Beijing's security perceptions, as it deepened Chinese suspicion about potential U.S.-Japanese containment. Here, the domestic politics factor was also clearly at work. In Japan, this was the rightward shift in its security orientation and the parallel strengthening of the "China threat" perception among the Japanese people stimulated by Koizumi-like conservative LDP politicians. Indeed, the 2004 National Defense Program Guidelines (NDPG) adopted by the Koizumi administration mentioned for the first time in a Japanese national security doctrine two specific countries as Japan's key security concerns, namely North Korea and China (Prime Minister of Japan and His Cabinet, 2004). In the meantime, as in China communist ideology proved insufficient to the PRC's leaders as a source of legitimacy in the postCold War period, the CCP continued to feed nationalism among the people while tolerating anti-Japan sentiments. Japan's treatment of the history issue under Koizumi and what was perceived as a move away from its postwar pacifism provided Beijing with the context for singling out Japan's foreign policy actions as "a cause of serious concern" for the international community (Chinese Government's Official Web Portal, 2005).

A strong proponent of a strengthened military alliance with Washington and more assertive Japanese security policy, Koizumi dispatched the SDF on noncombat missions to the Indian Ocean and Iraq, respectively. While these deployments demonstrated Tokyo's commitment to support its U.S. ally in the "war on terror," they also indicated Koizumi's ambitions for Japan's expanded international security presence. Indeed, according to the 2004 NDPG, Japan would now "improve the international security environment" as part of its defense policy (Prime Minister of Japan and His Cabinet, 2004). Arguably in line with the security ambitions of Koizumi and his conservative LDP, while at the same time reflecting the Bush administration's focus on strengthening its military partnership with Tokyo, the scope of the alliance was broadened as well. This was clear from the 2005 joint report entitled U.S.-Japan Alliance: Transformation and Realignment for the Future, which introduced an aspect of global cooperation to the bilateral security framework (Ministry of Foreign Affairs, Japan, 2005).

The PRC sharply criticized Japan's security activism under Koizumi. Driven by strong anti-Japanese nationalistic sentiments and to the extent of greatly exaggerating, Chinese analysts repeatedly expressed worries about Japan's alleged 
reemergence as a major military power, thereby contributing to souring SinoJapanese relations (Yahuda, 2006). The LDP's moves to revise Article 9 were seen by many observers in China as an indicator for a growing political conservatism in Japan (Wu, 2005), which further fueled suspicion regarding Tokyo's strategic intentions. China argued that the trend in Japanese security policy raised the question whether Japan would continue pursuing its postwar peaceful development policy or would instead once again follow the path of expansionism ("Japan's 'Sense of Crisis,'" 2005).

It was the Taiwan issue, however, that was of the utmost concern to China. Indeed, Beijing's fears of the alliance's interference in cross-Strait relations were exacerbated by a 2005 U.S.-Japanese statement that indicated the "peaceful resolution" of the Taiwan Strait issue as one of their "common strategic objectives" in the region (United States Department of State, 2005). In this regard, Premier Wen Jiabao stressed that Japan should adhere to the "one China" principle, while the security alliance was a bilateral arrangement ("Premier Wen," 2005). He also pointed out that the Chinese people regarded the alliance as interfering in the PRC's domestic affairs, something Beijing would not tolerate ("Premier Wen," 2005). China retaliated by enacting the Anti-Secession Law soon after the U.S.Japanese joint statement was issued. Beijing stated its position in Article 8 of the law, underscoring the possibility of a military action in case Taiwan declared its independence. Indeed, the law explicitly indicated the PRC's intention to employ "non-peaceful means" in order to "protect China's sovereignty and territorial integrity" (National People's Congress, PRC, 2005) and thereby prevent a change in the status quo across the Strait.

The Taiwan issue represents a complicated factor in Japan-China security relations. For Japan, a potential cross-Strait conflict between the United States and the PRC over the island would mean that Tokyo would be pressed to make tough choices concerning its involvement. In turn, Japan's decisions would inevitably have a profound impact on both the U.S.-Japan alliance and Sino-Japanese relations. Taiwan's relevance for Japan's national security has also a geopolitical dimension, due to the island's location close to Japan's SLOCs, which are vital for its economy. Arguably, this feeds Beijing's suspicion about Tokyo's real motives behind the strengthening of its security ties with Washington, as a unified China might be seen as a challenge to Japan's strategic interests in the Western Pacific. Indeed, analysts point out that the PRC's recent expansion of its naval power is part of a broader strategy, which seeks the establishment of Chinese maritime dominance over the Western Pacific (Minemura, 2009).

As far as the PRC's relations with the United States are concerned, the Taiwan issue remains a major (if not the major) factor that determines their stability. While the United States is a power that can further Chinese foreign policy goals, it is at the same time also perceived by many Chinese as a threat to the internal stability of their country (F. L. Wang, 2009; J. Wang, 2005). In this context, America's policy on Taiwan, aimed at maintaining peace in the Strait and deterring China from a forceful unification with the island (but also Taiwan from unilaterally changing the status quo), has raised questions in Beijing. Indeed, Chinese White Papers on Defense have repeatedly criticized the United States for selling advanced weapons to Taiwan and strengthening its military ties with the island (Information Office of the State Council of the PRC, 2004, 2006, 2008). 
China has urged Washington to strictly adhere to a "one China" policy and has emphasized the destabilizing impact of U.S. actions on cross-Strait relations. Moreover, it is also beyond question that a military confrontation over the island would have major repercussions for regional stability.

\section{Military Buildup and a Potential Arms Race in the Region}

The "action-reaction dynamics" between the U.S.-Japan alliance and China observed above are also evident in recent trends toward military buildups, which suggest a potential arms race in the region (Yamamoto, 2008). Specifically, this concerns new missile deployments by China, the joint U.S.-Japanese development of ballistic missile defense (BMD) systems, and the increased activism in space by Japan and China.

In the case of China, it has focused its efforts on attaining military superiority with regard to Taiwan, as well as on deterring the United States (and Japan) from helping Taipei achieve independence. While pursuing economic interdependence with the island and emphasizing the benefits of economic integration, Beijing has sought a more coercive approach to the reunification issue by means of reinforcing Chinese military capabilities and becoming more serious about the use of force (as seen in its adoption of the Anti-Secession Law). In this context, the PRC's modernization of its nuclear and missile arsenal has been particularly important. Some observers point out China's plans to deploy ballistic missiles with nonnuclear warheads and special guidance systems to hit aircraft carriers and warships far from its shores. Such moves would raise the stakes for a possible external intervention (by the United States and Japan) in a Taiwan crisis or any other regional conflict involving China (Richardson, 2009). China's rapid development and deployment since the mid-1990s of short- and intermediate-range missiles has already increased its ability of striking not only Taiwan, but also other targets in East Asia, including Japan and some of the main U.S. military bases in the region. Not surprisingly, and seen as a defensive measure from a Japanese perspective, this has triggered a response from Tokyo. Indeed, the 2007 Japanese White Paper on Defense expressed worries that Beijing's military modernization could be aiming at something more than the mere resolution of the Taiwan issue (Ministry of Defense, Japan, 2007).

It should be stressed that Japan's main incentive to seek acquisition of new military capabilities has been the DPRK's provocative behavior from the early 1990s onward and a perceived need for Tokyo to deter Pyongyang from engaging in military actions. However, the rise of Chinese military power has acted as an additional stimulus for Tokyo to seek a strengthening of its own defense capabilities. The changed domestic context of foreign policy has also facilitated this process. Indeed, some LDP politicians, especially Koizumi and his successor, Abe, arguably used the presence of new threats in East Asia and domestic sentiments favoring "normalization" to augment Japan's military power and expand its security role (Atanassova-Cornelis, 2010).

Japan's decision to engage with the United States in joint research on BMD was a direct response to the 1998 North Korean missile launch. Until the 1998 launch, Tokyo refrained from making a formal commitment to joint development out of consideration for Beijing's concerns that a U.S.-Japanese BMD system (especially 
a mobile and sea-based one) could neutralize Chinese nuclear deterrents and be used for the defense of Taiwan (Green, 2003). The launch heightened the security concerns in Japan and acted as a catalyst for a deepening of U.S.-Japan cooperation on BMD. In the wake of the second North Korean nuclear crisis in 2002-2003, Koizumi sought to accelerate the introduction of U.S.-made missile defense systems in late 2003, with the first systems deployed during the term of Abe. The introduction of BMD systems was viewed in positive terms by the general public, with $57 \%$ of the Japanese polled in 2006 supporting such a defense capability (Japan Cabinet Office, 2006). For China, however, these developments only served to deepen its suspicion about the real strategic intentions of Tokyo and Washington, especially concerning Taiwan. Furthermore, if Japan and the United States, but also potentially Taiwan, deploy BMD systems in the future, the PRC may seek a significant strengthening of its own missile arsenal and acquisition of a defense system in order to maintain its strike capabilities (Yamamoto, 2008). In turn, this would only exacerbate the "security dilemma" in the region (Yamamoto, 2008). Nevertheless, until now, China's nuclear modernization has been rather moderate, focused more on a qualitative than a quantitative upgrade, which suggests that Beijing has sought not to provoke such a dilemma.

The increased space activism and use of space for national security purposes by Japan and China also illustrate the recent trend toward a potential arms race in East Asia. In the same way as Japan's decision for acquisition of BMD systems was triggered by the 1998 North Korean missile launch, Tokyo's decision in 1998 to establish its own spy satellite program and to deploy from 2003 onward four reconnaissance satellites was underpinned by a perceived threat from the DPRK. However, Beijing's approach to space development as an essential part of its national security strategy has arguably stimulated Tokyo's own ambitions. Since the start of the 2000s, China has developed and deployed a number of different types of satellites, thereby significantly improving its capabilities in this area. In 2005, China successfully put in orbit a manned spacecraft and in 2007 demonstrated its ability to destroy its own satellite with a ground-based ballistic missile. One month after China's successful antisatellite test, Japan deployed its fourth spy satellite.

Indeed, Japan did not wait to be left lagging behind the PRC. A turning point in Japan's space policy was the decision by the government of Fukuda Yasuo (2007-2008) to enact a bill that allowed the use of space for defensive purposes. The new law opened up the way for Japan's acquisition of early-warning satellites to detect missile launches. Under Prime Minister Aso, Tokyo advanced further in its space development policy for national security purposes, with the country's first space policy plan finalized in April 2009. Not surprisingly, it came in the wake of North Korea's launch of a long-range rocket the same month.

China, for its part, reportedly plans to accelerate its space development program, most notably by means of launching an unmanned lunar probe project by 2013 and constructing a space station by 2020. This arguably has had an immediate impact on Japan, as a government panel of Democratic Party of Japan's (DPJ's) Prime Minister Hatoyama Yukio (2009-present) ${ }^{11}$ has reportedly embarked on discussing a proposal for the construction of a Japanese robotoperated base on the moon's south pole by 2020 ("Lunar Probe," 2009). The PRC's development of sophisticated space technology and its growing presence 
in space, and Japan's increased focus on space exploration in recent years do not in themselves mean an arms race in space. Nevertheless, as the development of sophisticated space technologies, such as reconnaissance satellites, embodies a military dimension, this recent trend in Chinese and Japanese security policies suggests that military competition in space may not be impossible to imagine in the not so distant future.

\section{Japanese and Chinese Security Policies in East Asia: Regional Cooperation and Sino-Japanese Rivalry}

In comparison to Japan's strategy based on an "America first, Asia second" approach (Yamamoto, 2008, p. 22), China's foreign policy strategy from the late 1990s on has emphasized the promotion of multilateralism in East Asia. Beijing's participation in various regional institutional arrangements has formed part of its "reassurance campaign" (Saunders, 2008), aimed at reducing the "China threat" perception and, linked to it, apprehension in the region regarding the PRC's rising (military) power. Especially in Southeast Asia, China has utilized multilateralism in combination with other soft power tools. At the same time, however, Beijing's active promotion of cooperation in regional fora reveals its perception of vulnerability in East Asia. This vulnerability stems from the unresolved Taiwan issue, as well as the need for the CCP leaders to promote regional stability in order to maintain the country's high levels of economic growth. In this context, Beijing is seen to pursue a diplomatic strategy in East Asia in order to increase its influence and hedge vis-à-vis the United States (and Japan).

Although Tokyo's foreign policy since the 1990s has, indeed, remained centered on bilateralism with the United States placing especially under Koizumi a stronger emphasis on the military instruments of power, Japan's regional strategy has significantly relied on soft power. Japan has been a major aid donor to Southeast Asian countries and an active supporter of regional institution building, which has represented a continuity of Tokyo's comprehensive approach to security since the Cold War era (Atanassova-Cornelis, 2010). That approach has reflected Japanese willingness to ensure East Asian stability by means of cooperation and deepened interdependence. Further, participation in various minilateral ${ }^{12}$ and multilateral fora has provided Tokyo with opportunities to pursue a policy of engagement, which has been described as a "key pillar" of its regional strategy (Yoshihara, 2008). Indeed, this has been Japan's preferred approach toward the PRC and the DPRK. Finally, as noted by some observers (e.g., Mulgan, 2005; Pempel, 2007), Chinese multilateral activism and competition for regional leadership with Beijing are seen to encourage Tokyo to raise its own diplomatic profile in East Asia and promote regional institution building.

\section{Northeast Asia: Multilateralism With Little Sino-Japanese Cooperation}

Northeast Asian multilateralism has arguably been underpinned by the common concern in the region about North Korea's nuclear program, which has drawn Japan, China, the United States, as well as South Korea (and Russia) closer together. 
In the case of Japan, it has actively utilized minilateral and multilateral fora to address the denuclearization of the DPRK, thereby pursuing its traditional policy of engagement toward Pyongyang (Hughes, 2005). To be sure, Tokyo's approach toward North Korea has hardened due to the politically sensitive abductee issue, which has become a major reason for Japan to refuse economic aid to and impose economic sanctions on the North. Nevertheless, Japan has supported a multilateral engagement of the DPRK and has participated in the Korean Peninsula Energy Development Organization (KEDO) ${ }_{1}^{13}$ the Trilateral Coordination and Oversight Group (TCOG) (with the United States and the Republic of Korea $[R O K])$, and the six-party talks. Furthermore, North Korea's military ambitions have provided the context for Japan and South Korea to intensify their security ties. Since the 1990s, Tokyo and Seoul have expanded their joint military exercises and coordinated, along with Washington, their policies toward Pyongyang in the TCOG framework. That policy coordination has been important for strengthening the trilateral Japan-U.S.-ROK relations.

Beijing, for its part, has been primarily concerned about the negative consequences of a potential military confrontation on the Korean Peninsula for its stability and the collapse of the Kim Jong-il regime. ${ }^{14}$ China has disagreed with the policy of pressure and sanctions against Pyongyang, thus pursuing an approach close to the South Korean position (especially under Roh Moo-hyun), according to which the best way to get out of the nuclear quagmire is through diplomatic means and strengthened inter-Korean economic ties (Lee, 2005). For Beijing, the need for a peaceful resolution of the North Korean issue has given a major impetus to promoting regional security cooperation in Northeast Asia. Indeed, the six-party talks, which commenced in 2003 and were the result of Chinese diplomatic efforts, have emerged as a major multilateral framework in the region for addressing the denuclearization of the DPRK.

So far, however, that forum has not succeeded in achieving its goal. ${ }^{15}$ Furthermore, the withdrawal of North Korea from the six-party talks in April 2009 and its subsequent insistence on direct negotiations with the United States and proposal for peace talks as a precondition to its return to the stalled dialogue in early 2010 have suggested a rather uncertain future for this multilateral framework. While it seems difficult to deny that Pyongyang has been in the driver's seat in this forum, the six-party talks had an unintended positive impact on the relations among the Northeast Asian states.

Indeed, the six-party talk framework has played a role in "avoiding the 'security dilemma' between the DPRK and the U.S.-Japan-ROK trilateral coalition" (Yamamoto, 2008, p. 26). The presence of such a dilemma would strengthen China's perception, in particular, of U.S.-Japan security cooperation as a threat to Beijing's interests with regard to Taiwan. The six-party talks have also had a positive impact on U.S.-China and China-South Korea relations, stimulating improved bilateral relations. Beijing's cooperation in the six-party talks has been of crucial importance to Washington, as China now may be regarded as the "sole supporter" of North Korea's economy and Kim Jong-il's regime (F. L. Wang, 2009). The importance attached by the United States to the North Korean nuclear issue and Washington's dependence on Beijing for its resolution provide China with bargaining power (Mahbubani, 2005), especially with regard to the Taiwan question: China cooperates with the United States on North Korea in return for 
U.S. nonsupport for Taiwanese independence. As far as South Korea is concerned, the convergence of its preference for engagement toward the North with China's policy of diplomatic resolution of the nuclear issue has arguably drawn the ROK closer to Beijing. Finally, in the wake of the DPRK's nuclear test in 2006, the probability of an arms race in Northeast Asia has emerged as a source of common concern for Beijing, Tokyo, and Seoul, leading to expectations for a strengthened trilateral cooperation, at least, in the short term (Zissis, 2006). Nevertheless, as far as Japan and China are concerned, there is a lack of coordination between both governments on North Korea (Yahuda, 2006), despite the commitment of both sides to a peaceful resolution of the nuclear issue, as well as their strong support for the six-party talks as the main mechanism of negotiation. The talks may not continue in the future and it is doubtful whether they will achieve the desired goal of North Korea's denuclearization; still, the possibility of another multilateral security framework in Northeast Asia emerging from these talks should not be excluded. Indeed, a new framework could provide opportunities for Japan and China to strengthen their cooperation on less sensitive, nontraditional security issues and thereby enhance regional institution building.

It should be stressed that the past couple of years have already seen greater willingness on the part of both Tokyo and Beijing to engage in closer collaboration on issues of common concern. An important factor for this has been the reduction of Japan's bilateral tensions with the PRC, and the ROK for that matter, over the "history issue" in the post-Koizumi era. Former Japanese Prime Minister Fukuda, in particular, advocated the strengthening of Tokyo's diplomatic ties with Beijing and Seoul and succeeded in reaching an agreement with them on the launch of an annual trilateral summit meeting independently of the Association of Southeast Asian Nations (ASEAN) summits. Based on a Japanese proposal, three-way talks among Japan, the PRC, and the ROK have been held since 1999 on the sidelines of ASEAN+3 (APT) summits. At the time, Beijing was reportedly reluctant to accept Tokyo's proposal for an independent summit, taking into consideration Pyongyang's wariness about such an exclusivist framework (Funatsuki \& Endo, 2008). Common concerns, such as natural disasters and pandemic diseases, have understandably brought the three neighbors together, and the first such summit took place in Japan in December 2008. It is hoped that the new framework will help Japan, China, and the ROK jointly tackle the various regional issues and promote regional integration in the economic area. This framework is also likely to provide a venue, especially for Tokyo and Beijing, for fostering mutual strategic trust, the lack of which remains a major challenge to regional stability.

Finally, given the suitability of minilateralism for addressing "hard" security issues, both Japan and China are seen to have sought the establishment of a trilateral policy dialogue with the United States. Japan was the initiator of what became in 1998 Track II three-way consultations among Tokyo, Beijing, and Washington. China, for its part, proposed the establishment of a trilateral framework at a senior official level during the George W. Bush administration; the first such meeting was planned for July 2009. The discussions were supposed to focus on various issues of common concern, including climate change and energy security, as well as the overall economic and political situation in East Asia. The talks were postponed, however, reportedly due to China's worries that such a 
meeting would anger North Korea given the tensions following the North's missile and nuclear tests in 2009 ("China Puts Brakes," 2009). Although doubts have been raised concerning the likelihood of such a trilateral dialogue emerging as a significant security mechanism in Northeast Asia (Jian, 2009), such an attempt indicates willingness on the part of China and Japan to alleviate the security dilemma and build trust.

\section{Southeast Asia: Multilateralism, Soft Power, and Sino-Japanese Rivalry}

Tokyo and Beijing have participated in various multilateral institutions and dialogues beyond the Northeast Asian region.

Japan has pointed out that the primary objective of its diplomacy in the wider Asia-Pacific is "to forge a stable and prosperous region in which long-term predictability is ensured" through mutual understanding and cooperation (Ministry of Foreign Affairs, Japan, 2009). In order to promote regional cooperation in the security field, Japan has played an important role in establishing the main security framework in the wider Asia-Pacific region, namely the ASEAN Regional Forum (ARF). Convened for the first time in 1994, the ARF was partly based on a 1991 proposal by Tokyo to create a region-wide security dialogue centered on the ASEAN Post-Ministerial Conference. While Tokyo's proposal and, in turn, the ARF reflected Japan's hope for regional stability by means of building mutual trust and preventing misunderstandings, the motivation to engage China was clearly an important one for Japan (Berger, 2004). In line with Japan's regional objectives, the ARF has envisaged the development of security cooperation in three stages, namely from confidence building to preventive diplomacy and, finally, to resolution of conflicts. In part because of Beijing's opposition, the forum has failed so far to institutionalize that process and has thus remained limited in its ability to tackle serious security issues, especially in Northeast Asia.

In recent years, China, for its part, has stressed the "great importance" it attaches to the role of the ARF for regional stability, emphasizing its commitment to the forum's further development and calling for the enhancement of mutual trust (Information Office of the State Council of the PRC, 2004, 2006, 2008). Beijing has hosted within the ARF framework seminars on cooperation on nontraditional security issues and held meetings on disaster relief and counterterrorism. China's increased participation in various multilateral organizations in the wider Asian region, including the ARF, has been part of its diplomatic efforts aimed at reassuring its neighbors of Beijing's benign intentions (Saunders, 2008). At the same time, the PRC's multilateral engagement of Asian states has provided it with opportunities to expand its regional influence and thereby limit the risk of being contained by a U.S.-led "coalition," while moving forward in pursuing military modernization. In order to reduce the suspicion in East Asia concerning the PRC's steadily rising military budget, Beijing has promoted a defensive image by stressing that China "will not pose a military threat to any other country" (Information Office of the State Council of the PRC, 2006), launching new security concepts, such as "peaceful development," and increasing its military transparency. The latter has included the publication of biannual White Papers on China's National Defense. 
The respective promotion by Japan and China of regional cooperation beyond the field of security, into the political and economic areas, and their rivalry for influence have been most pronounced in Southeast Asia. In this context, both Tokyo and Beijing have opted for soft power in order to secure regional influence.

Japan's main approach to Southeast Asia has been one of provision of Official Development Assistance (ODA). Together with investment, Tokyo's foreign aid was an important driver of East Asia's industrialization during the Cold War and ensured Japan's regional economic leadership (Pempel, 2007). For Tokyo, foreign aid has been directly linked to Japan's comprehensive interpretation of security since the postwar years, as well as to its promotion of "human security" objectives in East Asia and globally. ${ }^{16}$ Having emerged at the end of the 1990s as one of the global leaders in advocating human security, Japan under Koizumi revised its ODA charter in 2003 and indicated human security as one of the "basic policies" in its ODA policy. Indeed, Tokyo has been a primary aid donor to Southeast Asian nations, including Thailand, Indonesia, and the Philippines. Japan has extended ODA to these countries to support their economic and social development and to alleviate regional disparities. As the provision of foreign aid by Japan "has generated economic growth and jobs" in the region, Tokyo is seen to have "enhanced human security (in terms of health and wealth)" for many people in Southeast Asia (Lam, 2006, p. 149). Japan's human security role in the region has also included, among others, peacemaking and peacebuilding initiatives and humanitarian relief missions (Lam, 2006).

Beijing, for its part, has pursued an approach to Southeast Asia that reflects the emphasis the PRC places on economic growth as a means of achieving internal stability and, more recently, on soft power as a way of expanding its influence. The general acceptance in Southeast Asia (and Northeast Asia, for that matter) of the growing importance of China may be largely attributed to its economic growth and the benefits reaped from it, as the PRC has become a major driving force of the region's economic development. Furthermore, since the late 1990s China has actively used several policy tools to strengthen its soft power in Southeast Asia, including increased aid, public diplomacy (e.g., establishing Confucius institutes), and promotion of free trade agreements (FTAs; Kurlantzick, 2006). Beijing's diplomatic efforts have been rather successful, as the leaders of Southeast Asia no longer question the emergence of China (Kurlantzick, 2006).

The enhanced regional influence of the PRC, however, has naturally worried Tokyo. As pointed out by Mulgan (2005), Japan has traditionally (arguably in East Asia) been a source of soft power by virtue of its democratic political system, economic development model, and low (until recently) military profile. As stated above, Japan's foreign aid has been a major policy tool in its Southeast Asia diplomacy. However, due to financial constraints, Japan has since 2000 gradually decreased its ODA not only in Southeast Asia but also globally. As a result, after being the world's top donor of aid for 10 consecutive years, Tokyo moved down to fifth place in 2007. ${ }^{17}$ This constituted one of the examples of the perceived decline of Japan's economic power, affecting Tokyo's leadership position in the region and arguably fueling the rivalry with China.

Sino-Japanese rivalry has led to the "action-reaction" dynamics in Tokyo's and Beijing's respective policies in Southeast Asia. Largely in response to China's active engagement of ASEAN in the 1990s, Tokyo in 1997 proposed to 
institutionalize the Japan-ASEAN dialogue. This was a demonstration of Japanese willingness to strengthen its Southeast Asia diplomacy and to play a more active role in the region. Beijing, on the other hand, promoted the formalization of the "Asians only" APT process, launched in 1998. Japan has been very active in that grouping and supported, for example, the 2000 Chiang Mai Initiative for currency swaps. Nevertheless, since Tokyo was concerned that Washington's exclusion from the APT would open up the way for Beijing to expand its economic influence and leadership in regional institution building, Japan under Koizumi sought to keep Chinese ambitions in check by supporting the membership of Australia, New Zealand, and India in the new East Asia Summit (Mochizuki, 2007).

Similarly, Beijing's expansion of its ASEAN engagement through a proposal in 2001 for an ASEAN-China FTA and a decision in 2003 to sign the Treaty of Amity and Cooperation (TAC) as the first non-ASEAN member left Tokyo lagging behind. The Koizumi administration, however, countered China's regional activism by announcing in 2004 that Japan would join the TAC and by launching negotiations for an ASEAN-Japan FTA in 2005. While the recent "race" for concluding bilateral FTAs in the wider Asia-Pacific region is seen to be led by Beijing (Pempel, 2007), it was Tokyo that in the late 1990s was the first to initiate regional FTA negotiations and in 2002 signed its first-ever agreement with Singapore.

\section{Conclusion}

This article has examined the dynamics of Japanese and Chinese security policies in the region by focusing on elements in both countries' security policy behavior and in Sino-Japanese interactions that have a stabilizing and/or destabilizing impact on East Asia. Several observations may be made with regard to the implications for regional security.

First, as each side has taken steps to reinforce its respective stance on the status quo and thereby adjust to the post-Cold War strategic environment, the trend for a security dilemma in East Asia has been accentuated between Tokyo and Washington, on the one hand, and Beijing, on the other. Japan has responded to the North Korean nuclear threat and sought to balance China by means of strengthening its security ties with the United States together with its own defense posture. Beijing, however, has seen the reinforcement of the alliance as a potential threat to its core national security interest (i.e., the Taiwan issue). The PRC has focused on military modernization in order to deter Taiwan from moving toward independence, as well as to raise the stakes for a potential U.S.-Japanese involvement in what is regarded by the PRC as a domestic matter. The lack of strategic trust between Japan and China has fed the security dilemma, which is also noticeable in the recent trend toward an arms race in East Asia.

Second, while the present framework of major power relations may have a destabilizing effect on East Asian security in the long run, notably in the case of a Sino-Japanese or U.S.-China conflict, the balance of power currently maintained may be assessed in positive terms with regard to regional stability. In this context, Japan's willingness to enhance its regional role, namely in the Korean and Taiwan Strait theaters, has strengthened the deterring effect of the U.S. forward deployment in East Asia and hence should be seen as positive for counterbalancing a rising China (Mulgan, 2005; Yoshihara, 2008). Furthermore, as the Southeast 
Asian countries remain wary of the PRC's future strategic trajectory, a "diplomatic balance" between Tokyo and Beijing rather than "unilateral Chinese influence" (Mulgan, 2005, p. 112) remains the most preferred option in the region as a whole.

Finally, that "diplomatic balance" is already visible in the post-Cold War trends toward regional cooperation and multilateralism in East Asia. For Tokyo, its support for institution building, pursuit of economic diplomacy, and promotion of deepened interdependence have been an expression of Japan's peaceful foreign policy approach pursued since the postwar years. For Beijing, its active engagement of Southeast Asia and increased involvement in regional multilateral fora have served as a means to ease the worries in East Asia about China's potential emergence as a hostile power and promote its "peaceful rise." Further, while Japan and China each have used soft power tools to compete for regional influence, this competition has arguably contributed to strengthening East Asian institution building and hence fostered stability. Yet, the striking feature of that multilateralism is its failure to encourage cooperation between Tokyo and Beijing (Yahuda, 2006). They have arguably continued to perceive one another as strategic rivals rather than partners, although recent trends in Northeast Asian minilateralism raise hopes for cautious optimism regarding the future of SinoJapanese cooperation and hence East Asian stability.

This optimism is also based on the latest developments in regional relations, especially in Northeast Asia. In the first place, the policies of the new DPJ administration of Prime Minister Hatoyama suggest that Japan is somewhat distancing itself from its traditional U.S.-centrism in foreign policy. Hatoyama has called for a more "equal" alliance with Washington and has signaled his willingness to revise some of the major security agreements between Japan and the United States. ${ }^{18}$ Instead, he has emphasized the strengthening of Tokyo's ties with Beijing and Seoul, as well as advocated the formation of an "East Asian community." This is likely to open up the way for a further deepening of regional cooperation, especially in Northeast Asia, and alleviation of the security dilemma. To be sure, as of early 2010 it is still premature to evaluate the impact of Hatoyama's policies on regional relations or the U.S-Japan alliance. Second, the improved ties between the PRC and Taiwan in the post-Chen Shui-bian period mean that the Taiwan issue has become less of a point of instability in China's relations with the United States and Japan in the short term. This is not to say that tensions between Beijing and Washington, and Tokyo may not arise over other issues (e.g., Tibet in the case of the former and the disputed islands in the East China Sea in the case of the latter). These are likely to be manageable, however, given the fact that the present administrations in all three capitals strongly emphasize their willingness to maintain positive bilateral (and trilateral) relations. Finally, as the North Korean nuclear issue continues to drag on, it increasingly necessitates a collaborative and coordinated response on the part of all actors in Northeast Asia. Japan's increased emphasis on its Asian diplomacy and China's determination to push forward a mutually beneficial relationship with Tokyo mean that a major obstacle to regional cooperation may have been removed, a least for now.

The cautious optimism regarding East Asian stability outlined above is tempered by a realistic assessment of the mutual Sino-Japanese perceptions. Indeed, the lack of strategic trust between the two East Asian powers remains, underpinning the security dilemma in Northeast Asia, as well as the competitive policies of 
Tokyo and Beijing in Southeast Asia. For the time being, therefore, the following Chinese assessment seems an apt description of East Asian (in-)stability:

Major powers are stepping up their efforts to cooperate with each other [but they] continue to compete with and hold each other in check. ... All countries are attaching more importance to supporting diplomatic struggles with military means.... The Asia-Pacific security situation is stable on the whole.... However, there still exist many factors of uncertainty in [the region]. (Information Office of the State Council of the PRC, 2008)

\section{Acknowledgments}

The authors would like to thank the two anonymous reviewers for their very helpful suggestions and constructive comments.

\section{Notes}

${ }^{1}$ For the purposes of this article, East Asia is defined as comprising Northeast Asia (Japan, China, the two Koreas, and Taiwan), Southeast Asia (ASEAN-10), and the United States as the primary extraterritorial actor.

${ }^{2}$ For a detailed analysis of Japan's security normalization, see Hughes (2005).

${ }^{3}$ As defined by Nye (2003, p. 66), "soft power lies in the ability to attract and persuade rather than coerce" and "arises from the attractiveness of a country's culture, political ideals, and policies." Kurlantzick (2006) notes that Nye's original definition was more limited in scope, excluding, for example, foreign aid and investment, and formal diplomacy. In the Asian context, soft power has become a more encompassing concept and is seen to include all forms of exercising influence outside the area of (hard) security (Kurlantzick, 2006).

${ }^{4}$ In July 2006, North Korea fired seven missiles, which all landed in the Sea of Japan, and in October of the same year conducted its first nuclear test. In April 2009, it fired a Taepodong-2 long-range missile (under the guise of a satellite launch) and in May 2009 conducted a second nuclear test.

${ }^{5}$ In 2002, Kim Jong-il admitted to then-Japanese Prime Minister Koizumi Junichiro that the DPRK had indeed abducted Japanese citizens, which influenced the public's subsequent support for Abe Shinzo's "hard-line" policy on the North. While Pyongyang regards the abductees issue as closed, Tokyo demands further explanation about the kidnapped Japanese citizens and claims that the number of abductees was higher than originally admitted by the North in 2002. As a result, this issue remains a major obstacle to the normalization of Japan's diplomatic relations with the DPRK.

${ }^{6}$ For an examination of the territorial dispute, see Drifte (2008).

7The LDP's one-party rule from 1955 to 1993 is known as the "1955 political system."

${ }^{8}$ Article 9, also known as the "peace clause," renounces the use of military force as a legitimate instrument of statecraft and commits Japan to nonpossession of war potential. The official government interpretation of Article 9 is that Japan is permitted to maintain only the minimum level of armed force necessary for self-defense but is prohibited from exercising its right to collective self-defense.

${ }^{9}$ On Japanese public opinion concerning the use of force and the SDF overseas dispatch in the "war on terror," see Midford (2006).

${ }^{10}$ In contrast to the traditional conceptualization of security in military terms, comprehensive security goes beyond the military dimension to include economic, social, political, and environmental aspects of national security.

${ }^{11}$ In the latest Lower House elections in Japan, which took place at the end of August 2009, the opposition DPJ achieved a landslide victory. However, the declining approval ratings of the Hatoyama administration and the forthcoming Upper House elections make the future of the new government rather uncertain.

${ }^{12}$ Minilateralism has become an important characteristic of Asian multilateralism since the late 1990s. The term refers to security fora or dialogues, which have three of four participants, are usually conducted on an ad hoc basis, and primarily deal with traditional security issues (Cha, 2003). Cases in point are the U.S-Japan-ROK and U.S-Japan-Australia trilateral consultations, as well as the four-party talks among the United States, China, the ROK, and the DPRK, which took place at the end of the 1990s (in essence, being the predecessor of the six-party talks).

${ }^{13} \mathrm{KEDO}^{\prime} \mathrm{s}$ activities have been suspended since May 2006 due to a lack of progress on North Korea's de-nuclearization.

${ }^{14}$ China's policy toward the Korean Peninsula has been described as "no unification, no nukes" (see F. L. Wang, 2009). 


\footnotetext{
${ }^{15} \mathrm{An}$ analysis of the six-party talks goes beyond the scope of this article. For a concise examination of the perspectives of the six participating states, see De Ceuster and Melissen (2008).

${ }^{16}$ On the Japanese approach to human security, see Atanassova-Cornelis (2005).

${ }^{17}$ The top four donors are the United States, Britain, Germany, and France.

${ }^{18}$ The current tensions between Japan and the United States over the relocation of the U.S. Marine Corps Futenma Air Station in Okinawa prefecture are a case in point.
}

\section{References}

Atanassova-Cornelis, E. (2005). Japan and the "human security" debate: History, norms and pro-active foreign policy. Graduate Journal of Asia-Pacific Studies, 3(2), 58-74.

Atanassova-Cornelis, E. (2010). Foreign policy instruments and factors for policy change: Japan's security "normalization" reconsidered. Asian Journal of Social Science, 38(2), 277-304.

Berger, T. U. (2004). Japan's international relations: The political and security dimensions. In S. S. Kim (Ed.), The international relations of Northeast Asia (pp. 135-169). Lanham, MD: Rowman \& Littlefield.

Cha, V. D. (2003). Multilateral security in Asia and the U.S.-Japan alliance. In G. J. Ikenberry \& T. Inoguchi (Eds.), Reinventing the alliance: U.S.-Japan security partnership in an era of change (pp. 140-159). New York and Hampshire: Palgrave Macmillan.

China puts brakes on talks with Japan, U.S. (2009, July 31). The Japan Times. Retrieved February 17, 2010, from http://search.japantimes.co.jp/cgi-bin/nn20090731a4.html.

China slams U.S.-Japan defense ties, Xinhua says. (1999, May 25). Kyodo News. Retrieved February 16, 2010, from http://findarticles.com/p/articles/mi_m0WDQ/is_1999_May_31/ai_54889144.

Chinese Government's Official Web Portal. (2005, December 9). FM: Japan military "gossiping" hides issues. Retrieved February 14, 2010, from http://www.gov.cn/misc/2005-12/09/content_ 122487.htm.

De Ceuster, K., \& Melissen, J. (Eds.). (2008). Ending the North Korean nuclear crisis: Six parties, six perspectives. Clingendael Diplomacy Papers, No. 18. The Hague: Netherlands Institute of International Relations "Clingendael."

Drifte, R. (2008). Japanese-Chinese territorial disputes in the East China Sea-between military confrontation and economic cooperation. Working Paper 24, April. Asia Research Centre, London School of Economics \& Political Science.

Foot, R. (2006). Chinese strategies in a U.S.-hegemonic global order: Accommodating and hedging. International Affairs, 82(1), 77-94.

Funatsuki, K., \& Endo, T. (2008, December 16). Japan, China, ROK ties enter new phase. Daily Yomiuri. Retrieved December 23, 2008, from http:/ /www.yomiuri.co.jp/dy/index.htm.

Green, M. J. (2003). Japan's reluctant realism: Foreign policy challenges in an era of uncertain power (2nd ed.). New York and Basingstoke: Palgrave Macmillan.

Hughes, C. W. (2005). Japan's re-emergence as a "normal" military power. Reprinted. London and New York: Routledge.

Information Office of the State Council of the People's Republic of China. (2004). China's national defense in 2004. Retrieved February 11, 2010, from http://english.gov.cn/official/2005-07/28/ content_18078.htm.

Information Office of the State Council of the People's Republic of China. (2006). China's national defense in 2006. Retrieved February 11, 2010, from http:/ /www.china.org.cn/english/features / book/194421.htm

Information Office of the State Council of the People's Republic of China. (2008). China's national defense in 2008. Retrieved February 12, 2010, from http://english.gov.cn/official/2009-01/20/ content_1210227.htm.

Japan Cabinet Office. (2006). Jieitai Boei Mondai ni Kansuru Yoron Chosa [Opinion polls on the SelfDefense Forces and defense affairs]. Retrieved February 15, 2010, from http:/ /www8.cao.go.jp/ survey/y-index.html.

Japan's "sense of crisis" pure imagination. (2005, November 4). Xinhua. Retrieved February 12, 2010, from http://news.xinhuanet.com/english/2005-11/04/content_3729035.htm.

Jian, J. (2009, June 16). Doubts over US-China-Japan talks. World Security Network. Retrieved February 13, 2010, from http://www.globalsecuritynews.com/showArticle3.cfm?article_id= $17664 \&$ topicID $=63$.

Kurlantzick, J. (2006, June). China's charm: Implications of Chinese soft power. Policy Brief No. 47, pp. 1-8. Washington, DC: Carnegie Endowment for International Peace.

Lam, P. E. (2006). Japan's human security role in Southeast Asia. Contemporary Southeast Asia, 28(1), 141-159.

Lee, C. M. (2005). China's rise, Asia's dilemma. The National Interest, 81(Fall), 88-94.

Lunar probe panel eyes moon base by 2020. (2009, December 11). Daily Yomiuri. Retrieved December 13, 2009, from http://www.yomiuri.co.jp/dy/index.htm. 
Mahbubani, K. (2005). Understanding China. Foreign Affairs, 84(5), 49-60.

Midford, P. (2006). Japanese public opinion and the war on terrorism: Implications for Japan's security strategy. Policy Studies No. 27, East-West Center Washington. Retrieved February 12, 2010, from http://www.eastwestcenter.org/publications / search-for-publications/browse-alphabetic-listof-titles /?class_call=view\&pub_ID=2051.

Minemura, K. (2009, February 14). China ups ante with new flattops. Asahi Shimbun. Retrieved February 16, 2009, from http:/ / www.asahi.com/english.

Ministry of Defense, Japan. (2007). Defense of Japan (Annual White Paper). Retrieved February 16, 2010, from http://www.mod.go.jp/e/publ/w_paper/2007.html.

Ministry of Defense, Japan. (2008). Defense of Japan (Annual White Paper). Retrieved February 16, 2010, at http://www.mod.go.jp/e/publ/w_paper/2008.html.

Ministry of Foreign Affairs, Japan. (2004). Diplomatic bluebook. Retrieved February 22, 2010, from http://www.mofa.go.jp/policy/other/bluebook/2004/index.html.

Ministry of Foreign Affairs, Japan. (2005). U.S.-Japan alliance: Transformation and realignment for the future. Security Consultative Committee Document. October 29. Retrieved April 25, 2010, from http:/ /www.mofa.go.jp/region/n-america/us/security/scc/doc0510.html.

Ministry of Foreign Affairs, Japan. (2007). Diplomatic bluebook 2007. Retrieved February 22, 2010, from http://www.mofa.go.jp/policy/other/bluebook/2007/index.html.

Ministry of Foreign Affairs, Japan. (2009). Diplomatic bluebook 2009. Retrieved February 22, 2010, from http://www.mofa.go.jp/policy/other/bluebook/2009/html/index.html.

Mochizuki, M. M. (2007). Dealing with a rising China. In T. U. Berger, M. M. Mochizuki, \& J. Tsuchiyama (Eds.), Japan in international politics: The foreign policies of an adaptive state (pp. 229-255). Boulder, CO, and London: Lynne Rienner.

Mulgan, A. G. (2005). Why Japan still matters? Asia-Pacific Review, 12, 104-121.

National People's Congress, People's Republic of China. (2005, March 14). Anti-Secession Law. Retrieved February 20, 2010, from http:/ /www.china.org.cn/english/2005lh/122724.htm.

Nye, J. S. (2003). U.S. power and strategy after Iraq. Foreign Affairs, 82(4), 60-73.

Pempel, T. J. (2007). Japanese strategy under Koizumi. In G. Rozman, K. Togo, \& J. P. Ferguson (Eds.), Japanese strategic thought toward Asia (pp. 109-133). New York and Basingstoke: Palgrave Macmillan.

Premier Wen meets the press. (2005, March 14). Xinhua. Retrieved February 12, 2010, from http:// news.xinhuanet.com/english/2005-03/14/content_2695760_1.htm.

Prime Minister of Japan and His Cabinet. (2004). National defense program guideline for FY 2005 and after. Retrieved February 13, 2010, from http://www.kantei.go.jp/foreign/policy/2004/ 1210taikou_e.html.

Richardson, M. (2009, January 22). Beijing takes aim at U.S. aircraft carriers. The Japan Times. Retrieved February 11, 2010, from http:/ / search.japantimes.co.jp/cgi-bin/eo20090122a3.html.

Saunders, P. (2008). China's role in Asia. In D. Shambaugh \& M. Yahuda (Eds.), International relations of Asia (pp. 127-149). Lanham, MD: Rowman \& Littlefield.

Terrill, R. (2005). What does China want? Wilson Quarterly, 29(4), 50-61.

United States Department of State. (2005, February 19). Joint statement of the U.S.-Japan Security Consultative Committee. Retrieved October 11, 2009, from http:/ /www.state.gov/r/pa/prs/ps/ 2005/42490.htm.

Wang, F. L. (2009, September). A strategic play in Northeast Asia: China engages the two Koreas and the United States. Paper presented at the 5th ECPR General Conference, Potsdam, Germany.

Wang, J. (2005). China's search for stability with America. Foreign Affairs, 84(5), 39-48.

$\mathrm{Wu}, \mathrm{X}$. (2005). The end of the silver lining: A Chinese view of the U.S.-Japan alliance. The Washington Quarterly, 29(1), 119-130.

Yahuda, M. (2006). The limits of economic interdependence: Sino-Japanese relations. In A. I. Johnston \& R. S. Ross (Eds.), New directions in the study of China's foreign policy (pp. 162-185). Stanford, CA: Stanford University Press.

Yamamoto, T. (2008, July). Building a security community in East Asia and Japan's dilemma between bilateralism and multilateralism. Paper presented at the Second World International Studies Conference (WISC), Ljubljana, Slovenia.

Yoshihara, T. (2008). Japan's emerging strategic posture in Asia: Headed toward leadership or rivalry? In A. Gupta (Ed.), Strategic stability in Asia (pp. 59-86). Aldershot, UK, and Burlington, VT: Ashgate.

Zissis, C. (2006, October 16). Japan's new leader faces old problems with China and South Korea. Council on Foreign Relations. Retrieved February 20, 2010, from http:/ /www.cfr.org/publication/ 11738. 